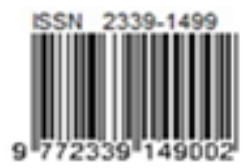

\title{
Analisis Kepuasan Pelanggan Terhadap Bauran Pemasaran Menggunakan Integrasi Importance Performance Analysis dan Model Kano (Studi Kasus : L'societe Dine and Bar Bandung)
}

\author{
Rizki Wahyuniardi ${ }^{1}$, Asep Syaifulbachri ${ }^{2}$, Rasyid Algaza ${ }^{3}$, \\ 1,2,3 Jurusan Teknik Industri, Fakultas Teknik, Universitas Pasundan \\ Jl. Setiabudhi No.193, Bandung 40153 \\ Email : 1rizki.wahyuniardi@unpas.ac.id, 2asep.syaifulbachri@gmail.com, ${ }^{3}$ algaza21@gmail.com
}

\begin{abstract}
The city of Bandung has a variety of culinary places that feature their own characteristics, ranging from luxury culinary venues, traditional uniqueness hangout, to the roadside hangout is available in this city. Amid the rapid development of culinary tourism in the city of Bandung, L'societe Dine and Bar is one restaurant that wrestle in culinary tourism business competition. However, according to sales data, L'societe experienced a decrease in total sales from 2014 to 2016 . L'societe requires effective improvement on its marketing mix performance. The study aims to analyze customer satisfaction with L'societe marketing mix. The research was conducted using descriptive statistics method, measuring customer satisfaction index and integration of Importance Performance Analysis and Kano Model. Based on the result of research, there are some attributes of L'societe marketing mix that need to be improved. For price attributes, L'societe should review product prices. This review is conducted through further research on product pricing by analyzing product prices with competitor product price comparison or optimizing production costs. For promotional attributes, L'societe can hold live music on an ongoing basis. In addition to this, it can be proposed packages with attractive discounts to the customer, group or family. This is important to consider because $L$ 'societe puts forward a convenient facility to its customers to feel different from its competitors.
\end{abstract}

Keywords: marketing mix, importance performance analysis, integration of importance performance analysis and canoe model, customer satisfaction, Kano model

\section{Abstrak}

Kota Bandung memiliki bermacam-macam tempat kuliner yang menyajikan ciri khas masingmasing, dari mulai tempat kuliner yang mewah, tempat nongkrong unik tradisional, sampai tempat nongkrong pinggiran jalan tersedia di kota ini. Ditengah pesatnya perkembangan wisata kuliner dikota Bandung, L'societe Dine and Bar merupakan salah satu restoran yang bergelut dalam persaingan bisnis wisata kuliner. Akan tetapi menurut data penjualan, L'societe mengalami penurunan total penjualan dari tahun 2014 - 2016. L'societe memerlukan perbaikan yang efektif atas kinerja bauran pemasarannya. Penelitian bertujuan menganalisis kepuasan pelanggan terhadap bauran pemasaran L'societe. Penelitian dilakukan menggunakan metode statistik deskriptif, pengukuran indeks kepuasan pelanggan serta integrasi Importance Performance Analysis dan Model Kano. Berdasarkan hasil penelitian, dihasilkan beberapa atribut bauran pemasaran L'societe yang perlu diperbaiki. Untuk atribut harga, L'societe harus melakukan peninjauan kembali harga produk. Peninjauan ini dilakukan melalui penelitian lebih lanjut mengenai harga produk dengan menganalisis harga produk dengan perbandingan harga produk pesaing ataupun melakukan optimasi biaya produksi. Untuk atribut promosi, L'societe dapat mengadakan live music secara berkesinambungan. Selain hal tersebut, dapat diusulkan paket-paket dengan diskon-diskon menarik kepada pasangan pelanggan, grup ataupun keluarga. Hal ini penting dipertimbangkan karena L'societe mengedepankan fasilitas yang nyaman kepada pelanggannya agar nuansa yang dirasakan berbeda dari para pesaingnya.

Kata kunci: bauran pemasaran, importance performance analysis, integrasi importance performance analysis dan model kano, kepuasan pelanggan, model kano 


\section{Pendahuluan}

Keindahan panorama alam, budaya, dan hawa sejuk Kota Bandung merupakan daya tarik tersendiri yang dimiliki Kota Bandung. Ditambah lagi ketenaran Kota Bandung sebagai kota wisata kuliner menjadikan kota ini sebagai estimasi para wisatawan baik lokal maupun internasional. Kota Bandung memiliki bermacam-macam tempat kuliner yang menyajikan ciri khas masing-masing, dari mulai tempat kuliner yang mewah, tempat nongkrong unik tradisional, sampai tempat nongkrong pinggiran jalan. Menurut data Dinas Kebudayaan dan Pariwisata Kota Bandung, pada tahun 2016, Kota Bandung memiliki 795 tempat kuliner yang terdiri dari restoran, tempat makan, café, dan bar. Hal ini menunjukan bahwa wisata kuliner berkembang pesat di Kota Bandung (lihat Tabel 1.)

Tabel 1. Jumlah cafe \& restoran di Kota Bandung

\begin{tabular}{|c|c|}
\hline Tahun & Jumlah Cafe \& restoran \\
\hline 2012 & 486 \\
\hline 2013 & 590 \\
\hline 2014 & 635 \\
\hline 2015 & 673 \\
\hline 2016 & 795 \\
\hline
\end{tabular}

Sumber : Dinas Kebudayaan dan Pariwisata Kota Bandung, 2016

Dari Tabel 1, dapat dilihat bahwa jumlah café dan restoran di Kota Bandung mengalami peningkatan tiap tahunnya. Tidak bisa dipungkiri peningkatan tersebut terpengaruh oleh kuatnya permintaan konsumen akan tempat wisata kuliner di Kota Bandung. Menurut Badan Pusat Statistik Kota Bandung pada tahun 2016 sebanyak 5 juta orang wisatawan mendatangi Kota Bandung, dimana jumlah wisatawan ini juga mempengaruhi peningkatan tempat wisata kuliner di Kota Bandung. Peningkatan ini menjadikan persaingan bisnis dibidang wisata kuliner semakin ketat. Oleh karena itu, perlu dilakukan upaya-upaya untuk mengantisipasi persaingan ketat wisata kuliner di Kota Bandung,

L'societe Dine and Bar merupakan salah brand rumah makan yang bergelut dalam persaingan usaha bisnis wisata kuliner di Kota Bandung. Brand ini mengusung konsep restaurant yang mewah, elegan, dan dining ala Perancis. Restauran ini menyediakan menu makanan Perancis yang disajikan oleh chef 74 berpengalaman dan memberikan suasana tempat yang ditata dengan suasana eropa yang elegan. Sofa, meja, sound system, dan peralatan-peralatan lainnya pada restauran ini memiliki kualitas yang tinggi. Ditambah lagi fasilitas penunjang seperti lounge, outdoor terrace, wifi, open kitchen kepada pelanggannya untuk memberikan pengalaman mengesankan saat berkunjung.

Akan tetapi dengan berbagai macam ciri khas dan keunggulan-keunggulan yang diberikan, perusahaan mengalami penurunan penjualan yang cukup meresahkan dari tahun 2014 hingga 2016.

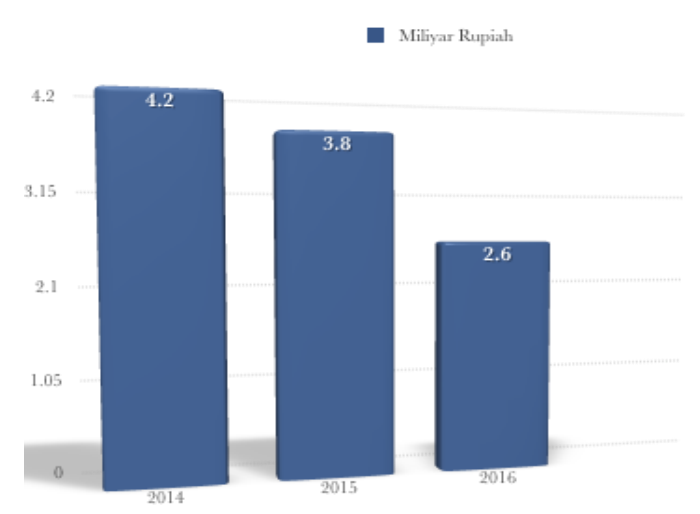

Gambar 1. Trend penjualan tahun $2014-2016$ Sumber : L'societe Dine and Bar, 2017

Dapat dilihat pada Gambar 1, total penjualan yang menurun pada tahun 20142016. Hal ini mengharuskan untuk melakukan perbaikan-perbaikan dan mengefektifkan kinerja pemasaran guna menaikan kembali total penjualan perusahaan.

Mengacu pada permasalahan tersebut, perlu dilakukan suatu perbaikan atau peningkatan kinerja. Suatu perbaikan atau peningkatan kinerja yang efektif dan efisien diperlukan penilaian kepentingan dan penilaian kinerja dari setiap atribut penting yang dimiliki. Dengan mengetahui atribut - atribut yang dinilai penting dimata konsumen maka dapat diketahui prioritas-prioritas yang paling penting untuk diperbaiki. Oleh karena itu analisis kepuasan pelanggan merupakan hal yang dapat menunjukan tingkat kepentingan dan kinerja.

Dalam penelitan ini digunakan integrasi Model Importance Performance Analysis (IPA) dan Model Kano untuk menganalisis kepuasan pelanggan terhadap bauran pemasaran. Pendekatan ini banyak digunakan oleh para peneliti untuk menganalisis kepuasan pelanggan (Puspitasari, Suliantoro, \& 
Kusumawardhani, 2010) (Ramadhan, Nasir Widha Setyanto, \& Efranto Yanuar Remba, 2013) (Indrasari, 2015) (Fatorahman \& Lestari, 2016) (Sugijanto \& Surabagiarta, 2016). Jika dalam penelitian tersebut digunakan 2 jenis kuesioner, penelitian ini hanya menggunakan sebuah kuesioner yang dibagikan kepada reponden yang sama.

Adapun tujuan dalam penelitian ini adalah (1) Mengetahui kondisi kinerja atas bauran pemasaran, (2) Mengetahui harapan pelanggan atas bauran pemasaran di L'societe, (3) Mengetahui kondisi kepuasan pelanggan atas bauran pemasaran di L'societe. Diharapkan penelitian ini dapat memberikan prioritas perbaikan atribut bauran pemasaran perusahaan.

\section{Metode Penelitian}

Metodologi dalam penelitian ini meliputi tahapan sebagai berikut :

1. Identifikasi masalah

Tahapan ini meliputi proses peneliti mendeskripsikan latar belakang penelitian dan merumuskan masalah-masalah yang akan diteliti. Dalam mendeskripsikan latar belakang penelitian penulis menjelaskan alasan-alasan mengapa penelitian ini dilakukan didasari masalah yang terjadi pada obyek penelitian serta tujuan dari penelitian ini dilakukan.

2. Tinjauan Pustaka

Tahapan ini meliputi proses peneliti menggunakan teori teori - teori, konsep, literature yang bersumber dari buku - buku ataupun jurnal digunakan untuk mendukung penelitian.

3. Menentukan dan menyusun instrument

Tahapan ini meliputi proses pembuatan kuesioner, dimana pertanyaan pertanyaan dalam kuesioner pada penelitian ini dibuat berdasarkan indikator yang ada pada variabel operasional. Variabel operasional dalam penelititan ini didasari atas penelitian Irawan, Sunarto, Aprilia, \& Jokom (2015). Pertanyaan digunakan untuk mengukur persepsi kinerja dan harapan pelanggan atas bauran pemasaran. Pada kuesioner dalam penelitian ini ditentukan skala likert sebagai skala yang digunakan dalam penelitian dengan 5 alternatif jawaban. Untuk menentukan jumlah sampel, dalam penelitian ini digunakan Slovin Formula untuk menentukan jumlah sampling.

4. Pengujian instrument

Tahapan pengujian dilakukan melalui dua tahap uji yaitu uji validitas dan uji realibitias. Uji validitas dilakukan untuk mengukur ketepatan kuesioner yang digunakan dalam penelitian, sedangkan uji realibilitas dilakukan untuk mengukur pernyataan konsisten atau stabil dari waktu ke waktu.

5. Pengumpulan data

Pengumpulan data dilakukan melalui dua tahap. Tahap yang pertama kuesioner dibagikan kepada 30 responden. Tahap ini merupakan tahap pre test yang dilakukan untuk mengetahui validitas dan realibititas. Setelah data yang didapat valid dan reliable barulah tahapan keseluruhan dilakukan dimana penulis menyebarkan kuesioner kepada responden sebanyak jumlah sampel yang telah ditentukan

6. Pengolahan data

Teknik pengolahan data yang dilakukan terbagi menjadi 5 , yaitu statistik deskriptif, pengukuran indeks kepuasan pelanggan, Importance Performance Analysis, Analogi Model Kano, serta Integrasi Importance Performance Analysis dan Model Kano

7. Analisis hasil olah data dan kesimpulan Tahapan ini merupakan tahapan terakhir dimana penulis menganalisis hasil dari keseluruhan olah data yang telah dilakukan lalu menyimpulkan hasil dari penelitian yang telah dilakukan.

\section{Statistik deskriptif}

Statisik deskriptif digunakan untuk menerjemahkan jawaban-jawaban tiap responden yang didapat melaui kuesioner. Berdasarkan jawaban - jawaban tersebut akan dibuat kriteria penilaian pada tiap item pertanyaan menggunakan persentase. Langkah-langkah kriteria penilaian adalah sebagai berikut: (Riduwan \& Sunarto, 2013 : 22)

a. Mencari jumlah skor ideal (skor tertinggi). Skor tertinggi didapat dengan mengalikan jumlah responden dengan skor penilaian terbesar

b. Mencari jumlah skor terendah. Skor terendah didapat dengan mengalikan jumlah responden dengan skor penilaian terkecil 
c. Menghitung skor penilaian. Skor penilaian didapat dengan mengalikan jawaban responden dengan nilai skor jawabannya lalu di rata - rata.

d. Mempersentasekan jawaban. Persentase didapat dengan membagi skor penilaian dengan skor tertinggi dikalikan 100\%

Setelah melakukan keempat tahap diatas maka akan didapat persentase penilaian kriteria interpretasi skor (Riduwan \& Sunarto, $2013: 23$ ). Adapun kriteria tersebut dapat dilihat pada Gambar 2.

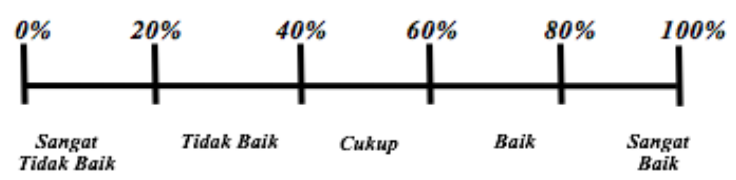

Gambar 2. Garis kriteria penilaian

Sumber : Riduwan \& Sunarto, 2013

\section{Indeks Kepuasan Pelanggan}

Di dalam melakukan pengukuran tingkat kepuasan, digunakan alat pengukuran menggunakan indeks kepuasan pelanggan. Rumusan indeks kepuasan pelanggan menurut Fandy Tjiptono dalam Taunay (2005) adalah :

$I K P=\frac{P P}{E X}$

Pers.

Keterangan :

IKP : indeks kepuasan pelanggan

PP: perceived peformance (kinerja yang dirasakan)

EX : expectation (harapan pelanggan)

Dimana kriteria pengukuran IKP :

$\mathrm{IKP}<1$, maka konsumen tidak puas

$\mathrm{IKP}=1$, maka konsumen puas

IKP $>1$, maka konsumen sangat puas

\section{Importance Permormance Analysis}

Identifikasi atribut pelayanan dengan
Importance Peformance Analysis,
menganalisis dan mengklasifikasikan atribut
kedalam kategori prioritas utama, pertahankan
prestasi, prioritas rendah, dan berlebihan.
Berikut dapat dilihat pembagian kuadran
dalam IPA pada Gambar 3 .
Langkah-langkah yang ditempuh untuk
pengerjaan Improtance Performance Analysis
adalah sebagi berikut:

a. Memposisikan sumbu vertikal dan horizontal pada grid IPA. Sumbu vertikal merupakan harapan dan sumbu horizontal merupakan kinerja. Sumbu vertikal dan horizontal saling berpotongan sehingga membagi diagram menjadi empat kuadran.

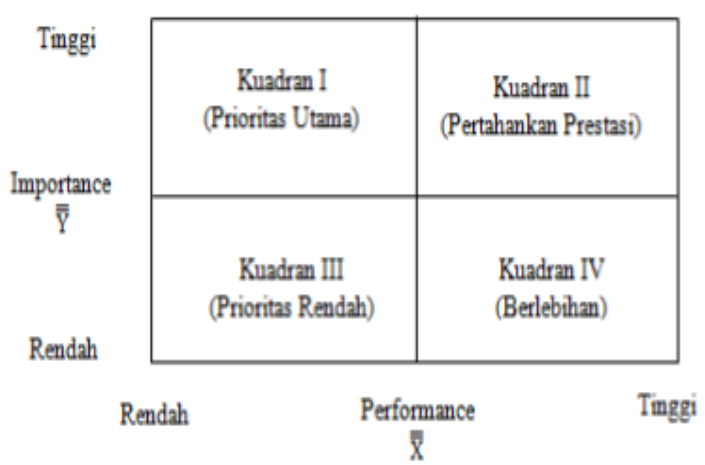

Gambar 3. Pembagian kuadran importance peformance analysis

Sumber : Ramadhan, et al : 2013

Adapun rumus yang digunakan untuk memposisikan grid vertikal dan horizontal pada IPA adalah sebagai berikut :

$$
\begin{aligned}
& \overline{\bar{X}}=\frac{\sum_{i=1}^{N} \bar{X}}{K} \\
& \bar{Y}=\frac{\sum_{i=1}^{N} \bar{Y}}{K}
\end{aligned}
$$

Pers. 2

Pers. 3

Keterangan :

$\overline{\bar{X}}$ : Rata-rata dari rata-rata skor tingkat kinerja seluruh atribut.

$\overline{\bar{Y}}$ : Rata-rata dari rata-rata skor tingkat harapan seluruh atribut.

$K$ : Banyaknya atribut yang mempengaruhi kepuasan.

b. Memasukan skor penilaian atribut kedalam grid IPA. Pada sumbu vertikal dimasukan skor penilaian harapan $(\bar{Y})$ tiap atribut dan pada sumbu horizontal dimasukan skor penilaian kinerja $(\bar{X})$ tiap atribut. Adapun rumus yang digunakan untuk skor penilaian adalah sebagai berikut : (Nugraha, Harsono, \& Adianto, 2014)

$\bar{X}=\frac{\sum X i}{n}$

Pers. 5

$\bar{Y}=\frac{\sum Y i}{n}$

Pers. 6

Keterangan :

$\bar{X}:$ Skor rata - rata penilaian kinerja

$\bar{Y}$ : Skor rata - rata penilaian harapan

$n$ : Jumlah responden.

c. Menganalisis grid kinerja dan kepentingan. Langkah ini merupakan tahap analisis tiap atribut - atribut yang masuk pada ke empat kuadran IPA yaitu Kuadran 1 (prioritas utama), Kuadran 2 (pertahankan 
prestasi), Kuadran 3 (prioritas rendah), Kuadran 4 (berlebihan). Hasil analisis akan menunjukan prioritas perbaikan pada tiap - tiap atribut.

\section{Model Kano}

Identifikasi atribut dengan Model Kano mengklasifikasikan atribut ke dalam kategori Kano yaitu antara lain Questionable (diragukan), Reverse (kemunduran), Attractive (menarik), Indifferent (Netral), One Dimensional (satu ukuran) dan Must be (keharusan).

Langkah - langkah yang ditempuh untuk pengerjaan Model Kano adalah sebagai berikut :

a. Mengklasifikasikan atribut kedalam model kano, langkah ini dilakukan menggunakan hasil jawaban penilaian tiap atribut pada kuesioner yang berisi pertanyaan pendapat pelanggan apabila indikator tersebut berjalan dengan baik (fungsional) dan pertanyaan pendapat pelanggan apabila indikator tersebut tidak berjalan dengan baik (disfungsional) (Nengsi, Lestari, \& Husna, 2012). Dari kedua jawaban tersebut kemudian digabungkan kedalam kategori kano padaTabel 2.

Tabel 2. Penentuan kategori model kano

\begin{tabular}{|c|c|c|c|c|c|}
\hline & \multicolumn{5}{|c|}{ Disfungsional } \\
\hline $\begin{array}{c}\text { Persyaratan } \\
\text { Pelanggan }\end{array}$ & $\begin{array}{l}\stackrel{\widetilde{3}}{=} \\
\stackrel{\tilde{n}}{-}\end{array}$ & 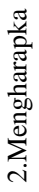 & 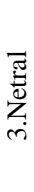 & 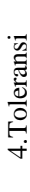 & 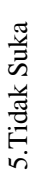 \\
\hline Fungsional & & & & & \\
\hline 1.Suka & Q & A & A & A & $\mathrm{O}$ \\
\hline 2.Mengharapkan & $\mathrm{R}$ & I & I & I & M \\
\hline 3.Netral & $\mathrm{R}$ & I & I & I & M \\
\hline 4.Toleransi & $\mathrm{R}$ & I & I & I & M \\
\hline 5.Tidak Suka & $\mathrm{R}$ & $\mathrm{R}$ & $\mathrm{R}$ & $\mathrm{R}$ & Q \\
\hline
\end{tabular}

Sumber : (Nofirza \& Kus Indrayani, 2011)
Keterangan :
Q: Questionable
$R$ : Reserve
A : Attractive
I: Indifferent
$O$ : One Demensional
$\mathrm{M}:$ Must be

b. Melakukan pengkategorian kano tiap - tiap atribut, kategori kano diklasifikasikan menggunakan Blaut's Formula (Walden, 1993) sebagai berikut (Sumber : Nofirza dan Indrayani, 2011)

- (Jika (one dimensional + attractive + must be) $>$ (indifferent + reserve + questionable) maka grade diperoleh dari yang paling maksimum dari kategori (one dimensional, attractive, must be).

- Jika (one dimensional + attractive + must be) $<$ (indifferent + reserve + questionable) maka grade diperoleh dari yang paling maksimum dari penjumlahan kategori (indifferent + reserve + questionable).

c. Menghitung nilai Better dan Worse, langkah ini dilakukan untuk mengetahui kemampuan atribut dalam memuaskan pelanggan. Better mengindikasikan seberapa besar kenaikan kepuasan pelanggan jika layanan disediakan. Worse mengindikasikan seberapa besar penurunan kepuasan pelanggan jika layanan tidak disediakan. Berikut adalah rumus untuk menghitung Better dan Worse adalah: (Nofirza \& Kus Indrayani, 2011)

$$
\begin{aligned}
& \text { Better }=\frac{A+O}{A+O+M+I} \\
& \text { Worse }=\frac{O+M}{A+O+M+I}
\end{aligned}
$$

Pers. 7

Pers. 8

d. Menganalisis hasil Model Kano. Langkah ini adalah langkah analisis tiap atribut yang telah diklasifikasikan kedalam kategori Model Kano. Hasil analisis akan menunjukan urutan prioritas perbaikan atribut dan seberapa besar kemampuan atribut dalam memuaskan pelanggan.

Untuk mendapatkan hasil dengan Metode Kano pada penelitan ini dilakukan penganalogian hasil kuesioner kepentingan dan kinerja menjadi penilaian fungsional dan disfungsional. Hal ini dilakukan untuk mempersingkat waktu serta mengefesienkan penelitan. Berdasarkan pengertian fungsional dan disfungsional (Nengsi et al., 2012), pendapat pelanggan apabila indikator tersebut berjalan dengan baik, maka untuk skor kuesioner harapan dapat diubah menjadi skor fungsional karena keduanya menanyakan pertanyaan yang hampir sama. Sedangkan berdasarkan pengertian disfungsional yaitu pendapat pelanggan apabila indikator tersebut berjalan dengan tidak baik, maka skor kuesioner kinerja diubah menjadi skor disfungsional dengan asumsi penilaian kinerja berbanding lurus dengan penilaian apabila indikator tersebut tidak terpenuhi. Didasari kemiripan hasil skor penilaian fungsional dan disfungsional tersebut maka dapat dilihat kategori Model Kano berdasarkan analogi pada Tabel 3 . 
Tabel 3. Penentuan kategori model kano berdasarkan analogi penulis

\begin{tabular}{|c|c|c|c|c|c|}
\hline \multirow[b]{2}{*}{$\begin{array}{l}\text { Persyaratan } \\
\text { Pelanggan }\end{array}$} & \multicolumn{5}{|c|}{ Kinerja } \\
\hline & 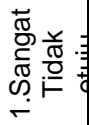 & 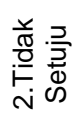 & 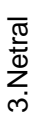 & 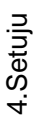 & 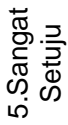 \\
\hline \multicolumn{6}{|l|}{ Harapan } \\
\hline 5.Sangat Penting & Q & $A$ & $A$ & $A$ & $\mathrm{O}$ \\
\hline 4.Penting & $\mathrm{R}$ & $\mathrm{I}$ & $\mathrm{I}$ & I & $\mathrm{M}$ \\
\hline 3.Netral & $\mathrm{R}$ & I & 1 & 1 & $\mathrm{M}$ \\
\hline 2.Tidak Penting & $\mathrm{R}$ & $\mathrm{I}$ & I & I & $\mathrm{M}$ \\
\hline 1.Sangat Tidak Penting & $\mathrm{R}$ & $\mathrm{R}$ & $\mathrm{R}$ & $\mathrm{R}$ & $Q$ \\
\hline
\end{tabular}

\section{Integrasi Importance Performance Analysis dan Model Kano}

Integrasi Importance Performance Analysis (IPA) dan Model Kano bertujuan untuk membantu dalam mengevaluasi kepuasan pelanggan, bukan hanya mengetahui apakah harapan konsumen telah terpenuhi atau belum tetapi juga sebagai pedoman untuk mengembangkan usahausaha dalam memperkuat atribut yang lemah dan mempercepat perkembangan inovasi pelayanan dengan mengidentifikasi atribut atribut. (Puspitasari et al., 2010).

Setelah didapat hasil dari IPA dan Model Kano maka keduanya dintegrasikan. Hasil dari penggabungan kemudian dikategorikan merujuk pada penelitian Kuo, Chen, \& Deng (2012) seperti terlihat di Tabel 4.

Tabel 4. Penentuan kategori integrasi IPA dan

\begin{tabular}{|c|c|c|c|c|c|}
\hline \multirow[b]{2}{*}{ Series } & \multirow{2}{*}{$\begin{array}{l}\mathscr{d} \\
\frac{\Phi}{\delta} \\
\frac{d}{\pi} \\
0\end{array}$} & \multirow{2}{*}{ 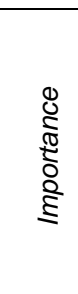 } & \multirow{2}{*}{ 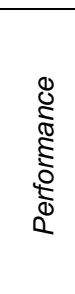 } & \multicolumn{2}{|c|}{$\begin{array}{c}\text { Strategi } \\
c \\
\text { Priorities } \\
\end{array}$} \\
\hline & & & & 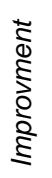 & 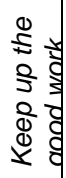 \\
\hline \multirow{4}{*}{$\begin{array}{c}\text { Hygine } \\
\text { (Must-be) }\end{array}$} & Survival & High & High & - & 1 \\
\hline & Fatal & High & Low & 1 & - \\
\hline & $\begin{array}{l}\text { Cronice } \\
\text { disasease }\end{array}$ & Low & Low & 2 & - \\
\hline & Fitness & Low & High & - & 2 \\
\hline \multirow{4}{*}{$\begin{array}{c}\text { War } \\
\text { (One } \\
\text { dimensional) }\end{array}$} & $\begin{array}{l}\text { Major } \\
\text { weapon }\end{array}$ & High & High & - & 3 \\
\hline & $\begin{array}{l}\text { Defenseless } \\
\text { strategy } \\
\text { point }\end{array}$ & High & Low & 3 & - \\
\hline & $\begin{array}{l}\text { Defenseless } \\
\text { zone }\end{array}$ & Low & Low & 4 & - \\
\hline & $\begin{array}{l}\text { Supportive } \\
\text { weapon }\end{array}$ & Low & High & - & 4 \\
\hline \multirow{4}{*}{$\begin{array}{c}\text { Treasure } \\
\text { (Attractive) }\end{array}$} & $\begin{array}{l}\text { Precious } \\
\text { treasure }\end{array}$ & High & High & - & 5 \\
\hline & $\begin{array}{l}\text { Dusty } \\
\text { diamond }\end{array}$ & High & Low & 5 & - \\
\hline & Rough stone & Low & Low & 6 & - \\
\hline & $\begin{array}{l}\text { Beginning } \\
\text { jewelry }\end{array}$ & Low & High & - & 6 \\
\hline
\end{tabular}

Sumber : Kuo et al., 2012

\section{Hasil dan Pembahasan}

\section{Statistik deskriptif}

Statistik deskriptif dilakukan untuk menerjemahkan jawaban-jawaban responden pada hasil kuesioner. Melalui kuesioner diperoleh data-data tanggapan responden mengenai harapan dan kinerja untuk tiap tiap atribut pada masing-masing dimensi. Rekapitulasi perhitungan statistik deskriptif tanggapan responden mengenai harapan dan tanggapan responden mengenai kinerja diperlihatkan pada Tabel 5 dan Tabel 6 .

Tabel 5. Tanggapan responden mengenai harapan

\begin{tabular}{|l|c|c|c|c|}
\hline \multicolumn{1}{|c|}{ Dimensi } & Skor & $\begin{array}{c}\text { Skor } \\
\text { Ideal }\end{array}$ & Persentase & Kriteria \\
\hline PRODUK & 2.273 & 2.580 & $88,1 \%$ & $\begin{array}{c}\text { Sangat } \\
\text { Baik }\end{array}$ \\
\hline HARGA & 1.884 & 2.150 & $87,6 \%$ & $\begin{array}{c}\text { Sangat } \\
\text { Baik }\end{array}$ \\
\hline LOKASI & 1.148 & 1.290 & $89 \%$ & $\begin{array}{c}\text { Sangat } \\
\text { Baik }\end{array}$ \\
\hline PROMOSI & 1.137 & 1.290 & $88,1 \%$ & $\begin{array}{c}\text { Sangat } \\
\text { Baik }\end{array}$ \\
\hline ORANG & 1.141 & 1.290 & $88,4 \%$ & $\begin{array}{c}\text { Sangat } \\
\text { Baik }\end{array}$ \\
\hline $\begin{array}{l}\text { FAS. } \\
\text { FISIK }\end{array}$ & 1.529 & 1.720 & $88,9 \%$ & $\begin{array}{c}\text { Sangat } \\
\text { Baik }\end{array}$ \\
\hline PROSES & 1.077 & 1.290 & $83,5 \%$ & Baik \\
\hline Total & $\mathbf{1 0 . 1 8 9}$ & $\mathbf{1 1 . 6 1 0}$ & $\mathbf{8 7 , 8 \%}$ & $\begin{array}{c}\text { Sangat } \\
\text { Baik }\end{array}$ \\
\hline
\end{tabular}

Sumber : Pengambilan Data 2017

Tabel 6. Tanggapan responden mengenai kinerja

\begin{tabular}{|l|c|c|c|c|}
\hline \multicolumn{1}{|c|}{ Dimensi } & Skor & $\begin{array}{c}\text { Skor } \\
\text { Ideal }\end{array}$ & $\begin{array}{c}\text { Persen- } \\
\text { tase }\end{array}$ & Kriteria \\
\hline PRODUK & 2.080 & 2.580 & $80,6 \%$ & Baik \\
\hline HARGA & 1.638 & 2.150 & $76,2 \%$ & Baik \\
\hline LOKASI & 927 & 1.290 & $71,9 \%$ & Baik \\
\hline PROMOSI & 817 & 1.290 & $63,3 \%$ & Cukup \\
\hline ORANG & 1.067 & 1.290 & $82,7 \%$ & Baik \\
\hline FAS. FISIK & 1.407 & 1.720 & $81,8 \%$ & Baik \\
\hline PROSES & 1.017 & 1.290 & $78,8 \%$ & Baik \\
\hline Total & $\mathbf{8 . 9 5 3}$ & $\mathbf{1 1 . 6 1 0}$ & $\mathbf{7 7 , 1 \%}$ & Baik \\
\hline
\end{tabular}

Sumber : Pengambilan Data 2017

Berdasarkan hasil statistik deskriptif dapat dilihat bahwa tanggapan responden mengenai harapan terhadap bauran pemasaran L'societe tergolong dalam kriteria sangat baik sedangkan tanggapan responden mengenai kinerja terhadap bauran pemasaran L'societe tergolong dalam kriteria baik.

\section{Indeks Kepuasan Pelanggan}

Pengukuran kepuasan pelanggan dilakukan dengan mengukur indeks kepuasan masing-masing atribut. Hasil rekap perhitungan untuk indeks kepuasan pelanggan tiap-tiap atribut dapat dilihat pada Tabel 7. 
Tabel 7. Rekapitulasi indeks kepuasan pelanggan

\begin{tabular}{|c|c|c|c|}
\hline Atribut & $\begin{array}{l}\text { Harapan } \\
\quad(Y)\end{array}$ & $\begin{array}{l}\text { Kinerja } \\
(\mathrm{X})\end{array}$ & $\begin{array}{l}\text { Indeks } \\
\text { Kepuasan }\end{array}$ \\
\hline \multicolumn{4}{|l|}{ PRODUK } \\
\hline Penampilan makanan yang disajikan L'societe menarik & 379 & 343 & 0,91 \\
\hline Penampilan minuman yang disajikan $L$ 'societe menarik & 354 & 359 & 1,01 \\
\hline Rasa makanan yang disajikan L'societe enak & 401 & 348 & 0,87 \\
\hline Rasa minuman yang disajikan L'societe enak & 378 & 348 & 0,92 \\
\hline Makanan disajikan L'societe berkualitas & 391 & 346 & 0,88 \\
\hline Minuman disajikan L'societe berkualitas & 370 & 336 & 0,91 \\
\hline \multicolumn{4}{|l|}{ HARGA } \\
\hline Harga yang ditawarkan L'societe terjangkau & 402 & 285 & 0,71 \\
\hline Harga yang ditawarkan L'societe sesuai dengan kualitas makanan & 382 & 349 & 0,91 \\
\hline Harga yang ditawarkan L'societe sesuai dengan kualitas minuman & 371 & 377 & 1,02 \\
\hline $\begin{array}{l}\text { Harga yang ditawarkan L'societe sesuai dengan porsi makanan yang } \\
\text { disajikan }\end{array}$ & 367 & 320 & 0,87 \\
\hline $\begin{array}{l}\text { Harga yang ditawarkan L'societe sesuai dengan porsi minuman yang } \\
\text { disajikan }\end{array}$ & 362 & 307 & 0,85 \\
\hline \multicolumn{4}{|l|}{ LOKASI } \\
\hline Lokasi L'societe berada di tempat yang mudah dijangkau & 375 & 374 & 1,00 \\
\hline Lokasi L'societe berada di tempat yang mudah ditemukan & 379 & 337 & 0,89 \\
\hline Area parkir L'societe memadai & 351 & 216 & 0,62 \\
\hline \multicolumn{4}{|l|}{ PROMOSI } \\
\hline Promosi L'societe berupa iklan / advertising di sosial media menarik & 362 & 257 & 0,71 \\
\hline Promosi L'societe berupa event menarik & 365 & 285 & 0,78 \\
\hline Promosi L'societe berupa diskon menarik & 387 & 275 & 0,71 \\
\hline \multicolumn{4}{|l|}{ ORANG } \\
\hline Karyawan L'societe bersikap sopan & 395 & 367 & 0,93 \\
\hline Karyawan L'societe tanggap dalam menangani kebutuhan konsumen & 388 & 347 & 0,89 \\
\hline $\begin{array}{l}\text { Karyawan } L \text { 'societe memiliki pengetahuan yang baik mengenai produk } \\
\text { yang ditawarkan }\end{array}$ & 358 & 353 & 0,99 \\
\hline \multicolumn{4}{|l|}{ FASILITAS FISIK } \\
\hline Desain interior L'societe menarik & 382 & 353 & 0,92 \\
\hline Desain eksterior L'societe menarik & 401 & 336 & 0,84 \\
\hline Fasilitas toilet yang disediakan L'societe bersih & 382 & 350 & 0,92 \\
\hline Suasana $L$ 'societe nyaman & 364 & 368 & 1,01 \\
\hline \multicolumn{4}{|l|}{ PROSES } \\
\hline Proses penyajian makanan L'societe cepat & 345 & 311 & 0,90 \\
\hline Proses penyajian minuman L'societe cepat & 350 & 340 & 0,97 \\
\hline Proses pembayaran L'societe cepat & 382 & 366 & 0,96 \\
\hline
\end{tabular}

Sumber : Pengambilan Data 2017

Berdasarkan pemaparan Tabel 7. dapat dilihat bahwa Indeks Kepuasan terendah terletak pada dimensi lokasi yang berkaitan dengan "Area parkir L'societe memadai" yaitu sebesar 0,62 dapat disimpulkan bahwa pelanggan L'societe merasa tidak puas dengan kinerja atribut tersebut dikarenakan nilai indeks bernilai dibawah 1. Sedangkan Indeks Kepuasan tertinggi terletak pada dimensi harga yang berkaitan dengan "Harga yang ditawarkan L'societe sesuai dengan kualitas minuman" yaitu sebesar 1,02 dapat disimpulkan bahwa pelanggan L'societe sudah sangat puas dengan kinerja atribut tersebut dikarenakan nilai indeks bernilai diatas 1 .

\section{Importance Performance Analysis}

Importance Performance Analysis
dilakukan untuk mendapatkan prioritas
perbaikan perbaikan tiap tiap atribut bauran
pemasaran dengan cara memetakan masing-

masing atribut menurut penilaian tingkat harapan dan kinerja. Berdasarkan hasil kuesioner, penilaian pelanggan terhadap harapan dan kinerja dirata rata. $\mathrm{Hal}$ ini dilakukan untuk menggambarkan sumbu horizontal $(\bar{X})$ dan sumbu Vertikal $(\bar{Y})$ pada IPA. Berikut adalah perhitungan $\bar{X}$ dan $\bar{Y}$ untuk penampilan makanan :

$\bar{X}$ Penampilan makanan $=\frac{343}{86}=3,99$

$\bar{Y}$ Penampilan makanan $=\frac{379}{86}=4,41$

Setelah didapatkan nilai $\bar{X}$ dan $\bar{Y}$ untuk setiap atribut kemudian dihitung kembali $\overline{\bar{X}}$ dan $\overline{\bar{Y}}$ keseluruhan atribut. Hal ini dilakukan untuk mendapatkan titik kecenderungan atau titik tengah pada pemetaan IPA. Perhitungan tersebut menggunakan rumus 2 dan 3 .

$\overline{\bar{X}}$ Penampilan makanan $=\frac{104,10}{27}=3,86$ 
$\overline{\bar{Y}}$ Penampilan makanan $=\frac{118,48}{27}=4,39$

Berdasarkan nilai $\bar{X}, \bar{Y}, \overline{\bar{X}}$, dan $\overline{\bar{Y}}$, dapat dilakukan pemetaan Importance Performance Analysis kedalam Scatter diagram. Untuk penampilan makanan dengan titik kecenderungan sebesar 4,39 dan 3,86 serta nilai $\bar{X}=3,99$ dan $\bar{Y}=4,41$ maka atribut penampilan makanan masuk kedalam Kuadran II dalam IPA. Hasil Pemetaan IPA dapat dilihat pada Gambar 4.

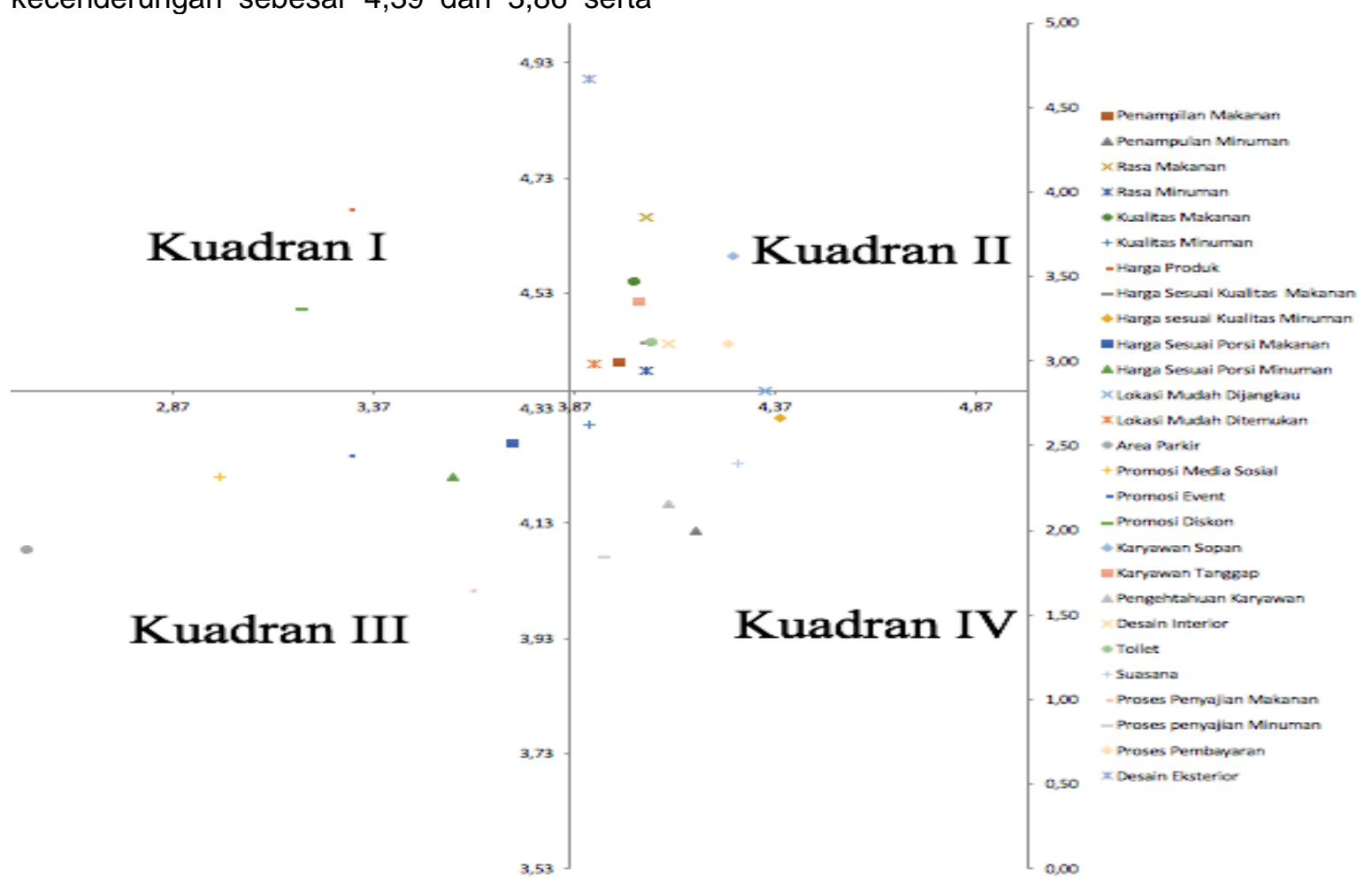

Gambar 4. Hasil pemetaan importance performance analysis

Sumber : Pengambilan Data 2017

Pada Gambar 4, dapat dilihat posisi atribut Bauran Pemasaran yang telah masuk kedalam kuadran - kuadran IPA. Dari diagram tersebut dapat dilihat bahwa semua atribut tersebar ke empat kuadran berbeda. Dari 27 atribut, hasilnya menunjukkan bahwa empat atribut pada kuadran 1, empat belas atribut berada pada kuadran 2, tiga atribut pada kuadran 3 , dan enam atribut berada pada kuadran 4.

\section{Model Kano}

Berdasarkan hasil dari kuesioner, kemudian identifikasi Model Kano dilakukan dengan menggabungkan kedua penilaian harapan dan kinerja lalu dimasukan kedalam dengan kategori kano telah diubah pada analogi model. Sebagai contoh responden 1 memberikan penilaian harapan penampilan makanan dengan skor 4 (Penting) dan penilaian kinerja penampilan makanan dengan skor 5 (Sangat Setuju) maka sesuai tabel kategori Model Kano didapat kategori $\mathrm{M}$ atau Must be. Jawaban dari 86 responden tersebut kemudian direkap. Dari 86 responden tersebut sebanyak 24 responden menghasilkan kategori Attractive, 9 kategori Must be, 11 One Dimensional, 2 Reverse, 1 Questionable, 39
Indiferrent untuk atribute penampilan makanan. Hasil dari rekap kemudian dilakukan perhitungan Blaut's Formula untuk mendapatkan hasil akhir kategori Model Kano. Selanjutnya dihitung nilai Better dan Worse. Hasil rekapitulasi identifikasi model kano untuk tiap attribute dapat dilihat pada Tabel 8.

\section{Integrasi Importance Performance Analysis dan Model Kano}

Integrasi dilakukan dengan menggabungkan hasil dari Importance Performance Analysis dengan Model Kano. Penggabungan dari kedua hasil dari metode ini akan menghasilkan pengkategorian baru dari tiap atribut bauran pemasaran. Dimana pengkategorian ini mengacu pada penelitan Kuo et al. (2012). Untuk Atribute penampilan makanan masuk pada kategori IPA Kuadran II dan Kategori Kano Attractive sehingga sesuai dengan tabel kategori Kano IPA atribut penampilan makanan dikategorikan sebagai Precious Treasure. Berikut hasil dari integrasi IPA dan Model Kano pada Tabel 9. 
Tabel 8. Rekapitulasi identifikasi model kano

\begin{tabular}{|c|c|c|c|c|c|c|c|c|c|}
\hline \multirow{2}{*}{ No } & \multicolumn{6}{|c|}{ Kano } & \multirow[b]{2}{*}{ Kategori } & \multirow{2}{*}{$\underset{\Phi}{\stackrel{ \pm}{ \pm ٍ ~}}$} & \multirow{2}{*}{ 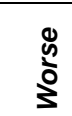 } \\
\hline & A & M & 0 & $\mathbf{R}$ & $\mathbf{Q}$ & I & & & \\
\hline 1 & 24 & 9 & 11 & 2 & 1 & 39 & Attractive & 0,42 & 0,24 \\
\hline 2 & 12 & 23 & 5 & 0 & 0 & 46 & Indifferent & 0,20 & 0,33 \\
\hline 3 & 35 & 8 & 20 & 0 & 2 & 21 & Attractive & 0,65 & 0,33 \\
\hline 4 & 29 & 10 & 9 & 0 & 0 & 38 & Attractive & 0,44 & 0,22 \\
\hline 5 & 30 & 13 & 15 & 1 & 2 & 25 & Attractive & 0,54 & 0,34 \\
\hline 6 & 29 & 15 & 8 & 2 & 0 & 32 & Attractive & 0,44 & 0,27 \\
\hline 7 & 53 & 2 & 0 & 2 & 6 & 23 & Attractive & 0,68 & 0,03 \\
\hline 8 & 28 & 16 & 10 & 1 & 0 & 31 & Attractive & 0,45 & 0,31 \\
\hline 9 & 15 & 30 & 12 & 0 & 0 & 29 & Must be & 0,31 & 0,49 \\
\hline 10 & 24 & 6 & 3 & 0 & 0 & 53 & Indifferent & 0,31 & 0,10 \\
\hline 11 & 14 & 9 & 5 & 3 & 2 & 53 & Indifferent & 0,23 & 0,17 \\
\hline 12 & 12 & 28 & 26 & 1 & 1 & 18 & Must be & 0,45 & 0,64 \\
\hline 13 & 26 & 13 & 9 & 2 & 0 & 36 & Attractive & 0,42 & 0,26 \\
\hline 14 & 13 & 6 & 0 & 13 & 1 & 53 & Indifferent & 0,18 & 0,08 \\
\hline 15 & 31 & 1 & 2 & 1 & 1 & 50 & Indifferent & 0,39 & 0,04 \\
\hline 16 & 28 & 4 & 1 & 5 & 5 & 43 & Indifferent & 0,38 & 0,07 \\
\hline 17 & 42 & 6 & 2 & 0 & 0 & 36 & Attractive & 0,51 & 0,09 \\
\hline 18 & 27 & 8 & 23 & 1 & 1 & 26 & Attractive & 0,60 & 0,37 \\
\hline 19 & 35 & 11 & 9 & 0 & 0 & 31 & Attractive & 0,51 & 0,23 \\
\hline 20 & 16 & 22 & 10 & 2 & 0 & 36 & Must be & 0,31 & 0,38 \\
\hline 21 & 31 & 10 & 12 & 1 & 0 & 32 & Attractive & 0,51 & 0,26 \\
\hline 22 & 55 & 1 & 2 & 1 & 0 & 27 & Attractive & 0,67 & 0,04 \\
\hline 23 & 29 & 15 & 13 & 2 & 0 & 27 & Attractive & 0,50 & 0,33 \\
\hline 24 & 16 & 21 & 9 & 0 & 0 & 40 & Must be & 0,29 & 0,35 \\
\hline 25 & 10 & 2 & 1 & 1 & 0 & 72 & Indifferent & 0,13 & 0,04 \\
\hline 26 & 8 & 15 & 4 & 0 & 0 & 59 & Indifferent & 0,14 & 0,22 \\
\hline 27 & 26 & 14 & 12 & 0 & 0 & 34 & Attractive & 0,44 & 0,30 \\
\hline
\end{tabular}

Sumber : Pengambilan Data 2017

Tabel 9. Rekapitulasi hasil integrasi importance performance analysis dan model kano

\begin{tabular}{|c|c|c|c|}
\hline Atribut & $\begin{array}{l}\text { Kategori } \\
\text { IPA }\end{array}$ & $\begin{array}{l}\text { Kategori } \\
\text { Kano }\end{array}$ & Kategori IPA - Kano \\
\hline \multicolumn{4}{|l|}{ PRODUK } \\
\hline Penampilan makanan yang disajikan L'societe menarik & Kuadran II & Attractive & Precious Treasure \\
\hline Penampilan minuman yang disajikan L'societe menarik & Kuadran IV & Indifferent & Eleminated \\
\hline Rasa makanan yang disajikan L'societe enak & Kuadran II & Attractive & Precious Treasure \\
\hline Rasa minuman yang disajikan L'societe enak & Kuadran II & Attractive & Precious Treasure \\
\hline Makanan disajikan L'societe berkualitas & Kuadran II & Attractive & Precious Treasure \\
\hline Minuman disajikan L'societe berkualitas & Kuadran IV & Attractive & Beginning Jewelry \\
\hline \multicolumn{4}{|l|}{ HARGA } \\
\hline Harga yang ditawarkan L'societe terjangkau & Kuadran I & Attractive & Dusty Diamond \\
\hline $\begin{array}{l}\text { Harga yang ditawarkan L'societe sesuai dengan kualitas } \\
\text { makanan }\end{array}$ & Kuadran II & Attractive & Precious Treasure \\
\hline $\begin{array}{l}\text { Harga yang ditawarkan L'societe sesuai dengan kualitas } \\
\text { minuman }\end{array}$ & Kuadran IV & Must be & Fitness \\
\hline $\begin{array}{l}\text { Harga yang ditawarkan } L \text { 'societe sesuai dengan porsi } \\
\text { makanan yang disajikan }\end{array}$ & Kuadran III & Indifferent & Eleminated \\
\hline $\begin{array}{l}\text { Harga yang ditawarkan } L \text { 'societe sesuai dengan porsi } \\
\text { minuman yang disajikan }\end{array}$ & Kuadran III & Indifferent & Eleminated \\
\hline \multicolumn{4}{|l|}{ LOKASI } \\
\hline Lokasi L'societe berada di tempat yang mudah dijangkau & Kuadran II & Must be & Survival \\
\hline Lokasi L'societe berada di tempat yang mudah ditemukan & Kuadran II & Attractive & Precious Treasure \\
\hline Area parkir L'societe memadai & Kuadran I & Indifferent & Eleminated \\
\hline \multicolumn{4}{|l|}{ PROMOSI } \\
\hline $\begin{array}{l}\text { Promosi L'societe berupa iklan / advertising di sosial media } \\
\text { menarik }\end{array}$ & Kuadran III & Indifferent & Eleminated \\
\hline Promosi L'societe berupa event menarik & Kuadran I & Attractive & Dusty Diamond \\
\hline Promosi L'societe berupa diskon menarik & Kuadran I & Attractive & Dusty Diamond \\
\hline
\end{tabular}




\begin{tabular}{|l|c|c|c|}
\hline Atribut & $\begin{array}{c}\text { Kategori } \\
\text { IPA }\end{array}$ & $\begin{array}{c}\text { Kategori } \\
\text { Kano }\end{array}$ & Kategori IPA - Kano \\
\hline ORANG & Kuadran II & Attractive & Precious Treasure \\
\hline Karyawan L'societe bersikap sopan & Kuadran II & Attractive & Precious Treasure \\
\hline $\begin{array}{l}\text { Karyawan L'societe tanggap dalam menangani kebutuhan } \\
\text { konsumen }\end{array}$ & Kuadran IV & Must be & Fitness \\
\hline $\begin{array}{l}\text { Karyawan L'societe memiliki pengetahuan yang baik } \\
\text { mengenai produk yang ditawarkan }\end{array}$ & Kuadran II & Attractive & Precious Treasure \\
\hline FASILITAS FISIK & Kuadran II & Attractive & Precious Treasure \\
\hline Desain interior L'societe menarik & Kuadran II & Attractive & Precious Treasure \\
\hline Desain eksterior L'societe menarik & Kuadran IV & Must be & Fitness \\
\hline Fasilitas toilet yang disediakan L'societe bersih & Kuadran III & Indifferent & Eleminated \\
\hline Suasana L'societe nyaman & Kuadran IV & Indifferent & Eleminated \\
\hline PROSES & Kuadran II & Attractive & Precious Treasure \\
\hline Proses penyajian makanan L'societe cepat
\end{tabular}

Sumber : Pengambilan Data 2017

\section{Kesimpulan}

Setelah melakukan penelitan mengenai analisis kepuasan pelanggan terhadap bauran pemasaran menggunakan integrasi Importance Performance Analysis dan Model Kano, maka ditarik kesimpulan sebagai berikut ini :

1. Tanggapan responden mengenai harapan terhadap bauran pemasaran L'societe tergolong dalam kriteria sangat baik. Hal ini dapat diartikan atribut-atribut bauran pemasaran L'societe memiliki tingkat harapan atau kepentingan yang tinggi dimata konsumen.

2. Tanggapan responden mengenai kinerja terhadap bauran pemasaran L'societe tergolong dalam kriteria baik. Hal ini dapat diartikan atribut-atribut bauran pemasaran L'societe sudah melakukan kinerja yang baik dimata konsumen.

3. Berdasarkan hasil pengukuran Indeks Kepuasan, nilai indeks terendah dimiliki atribut "Area parkir L'societe memadai". Hal ini dapat disimpulkan bahwa pelanggan belum puas akan area parkir yang ada di L'societe. Sedangkan nilai indeks tebesar dimiliki oleh atribut "Harga yang ditawarkan L'societe sesuai dengan kualitas minuman",sehingga dapat disimpulkan bahwa pelanggan sudah puas akan harga yang sesuai dengan kualitas minuman yang ada di L'societe. Setelah dilakukan integrasi Importance Performance Analysis dan Model Kano maka telah didapatkan prioritas strategi perbaikan untuk atribut bauran pemasaran L'societe. Atribut yang memerlukan perbaikan yaitu atribut Harga yang ditawarkan L'societe terjangkau,
Promosi L'societe berupa event menarik, dam Promosi L'societe berupa diskon menarik.

\section{Daftar Pustaka}

Dinas Kebudayaan dan Pariwisata Kota Bandung. (2016). Jumlah Café Dan Restaurant 2016. Bandung : Badan Pusat Statistik.

Fatorahman, F., \& Lestari, Y. D. (2016). Analisis Kualitas Layanan Perpustakaan Kampus B Universitas Airlangga Melalui Integrasi Importance Performance Analysis (IPA), Dan Model Kano Serta Usulan Perbaikannya Menggunakan Cause And Effect Diagram. Jurnal Manajemen Teori Dan Terapan/ Journal of Theory and Applied Management, 8(2), 93-110.

Indrasari, A. (2015). Integrasi Metode IPA dan Model Kano dalam Pengembangan Kualitas Pelayanan Perpustakaan. Jurnal IImiah Teknik Industri, 3(1), 45-52.

Irawan, D., Sunarto, A., Aprilia, A., \& Jokom, R. (2015). Analisis Bauran Pemasaran Terhadap Minat Beli Ulang Konsumen di Restoran Ikan Bakar Cianjur Surabaya. Jurnal Hospitality Dan Manajemen Jasa, 3(2), 475-488.

Kuo, Y. F., Chen, J. Y., \& Deng, W. J. (2012). IPA-Kano model: A new tool for categorising and diagnosing service quality attributes. Total Quality Management and Business Excellence, 23(7-8), 731-748.

Nengsi, S. A. F., Lestari, R., \& Husna, R. (2012). Integrasi Metode Importance Performance Analysis Dan Model Kano Dalam Peningkatan Kualitas Pelayanan ( Studi Kasus: Perpustakaan Universitas 
Andalas ). Jurnal Matematika UNAND, 5(3), 31-39.

Nofirza, \& Kus Indrayani. (2011). Aplikasi Metode Kano dalam Analisis Indikator Kualitas Pelayanan di Rumah Sakit Arifin Ahmad Pekanbaru. Jurnal Sains, Teknologi Dan Industri, 9(1), 1-8.

Nugraha, R., Harsono, A., \& Adianto, H. (2014). Usulan Peningkatan Kualitas Pelayanan Jasa pada Bengkel " $X$ " Berdasarkan Hasil Matrix ImportancePerformance Analysis. Jurnal Online Institut Teknologi Nasional, 01(03), 174-184.

Puspitasari, N. B., Suliantoro, H., \& Kusumawardhani, L. (2010). Analisis Kualitas Pelayanan Dengan Menggunakan Integrasi Importance Performance Analysis (IPA) dan Model Kano (Studi Kasus di PT . Perusahaan Air Minum Lyonnaise Jaya Jakarta).J@ti Undip, V(3), 185-198.

Ramadhan, E. W., Nasir Widha Setyanto, \& Efranto Yanuar Remba. (2013). Analisis Kepuasan Konsumen Terhadap Kualitas
Pelayanan Dengan Penerapan Importance Performance Analysis (IPA) Dan Model Kano. Rekayasa Dan Manajemen Sistem Industri, 1(2), 183-193.

Riduwan, \& Sunarto. (2013). Pengantar Statistika untuk Penelitian Pendidikan, Sosial, Ekonomi, Komunikasi, dan Bisnis. Alfabeta Bandung.

Sugijanto, \& Surabagiarta, I. K. (2016). Analisis Tingkat Layanan Terhadap Kepuasan Pelanggan Dengan Pendekatan Model Kano dan Importance Performance Analysis (IPA). Majalah Ekonomi, XXI(1), 61-77.

Taunay, E. G. P. (2005). Analisis Kepuasan Konsumen Terhadap Kualitas Pelayanan Jasa Kesehatan (Studi Kasus di Rumah Sakit Bhakti Wira Tamtama Semarang). Majalah Ilmiah Universitas Pandanaran, 8(16), 2-19. 
DOI: http://dx.doi.org/10.26593/jrsi.v7i2.2881.73-84

Halaman ini sengaja dikosongkan This page is intentionally left blank 